\title{
Tax-related and Economic Consequences of Selecting the Method of Debt Financing of Companies with Regard to Thin Capitalisation in OECD Member Countries
}

\author{
Dominik Gajewski
}

ABSTRACT

KEY WORDS:

JEL Classification:

\begin{abstract}
The following paper explores the issue of thin capitalisation in Organisation for Economic Cooperation and Development (OECD) member countries. There are two methods used by financing companies that are strongly related to this phenomenon: debt and equity financing. The tax-related consequences arising from choosing the debt financing method in companies with regard to thin capitalisation are analysed in this paper. It is argued that it is the tax policy of a company that directly influences the economic consequences of its operation. The taxation of thin capitalisation may be carried out in various forms depending on the adopted method. The tax-related implications point to the complexity of this process regardless of the country in which it takes place. However, the problem becomes even more complicated in the case of taxation of this process in companies undertaking cross-border activity.
\end{abstract}

corporate income tax; thin capitalisation; OECD

$\mathrm{H} 21, \mathrm{H} 25$

\section{Introduction}

The following paper i concerned with presenting the phenomenon of thin capitalisation within the context of companies operating in OECD member countries and the economic consequences of their activity. Thin capitalisation is a process that is strictly economic in nature. The key factor in the evaluation of the process of thin capitalisation is its tax-related consequences. In fact, consideration of the tax-related effect determines the commencement of this process in the first place. It is worth noting Calusing's (2007, p. 118) words that

-

Correspondence concerning this article should be addressed to: Dominik Gajewski University of Finance and Management in Warsaw, ul. Pawia 55, 01-030 Warsaw, Poland, e-mail: d.gajewski@op.pl well-developed OECD member countries introduce tax rates maximising the earnings from income tax. This burden is borne mainly by economic entities with the business status of a company.

The necessary element in the evaluation of the process of thin capitalisation is the means (method) of its implementation. Companies may choose between two methods: debt or equity financing. However, to select the most appropriate method, it is crucial to understand its tax-related implications. Because no general rule exists, each company should carry out an individual assessment of its situation, taking into account the actual tax-related consequences. Moreover, one should bear in mind that thin capitalisation is usually discussed in relation to the standards of the OECD Model Tax Convention, which is applicable for EU countries. This paper poses a thesis that the tax-related implications 
suggest that thin capitalisation (introduced by means of debt financing) is a positive phenomenon from an economic point of view. To perform such an assessment, one must carry out an analysis of tax regulations from which conclusions may be drawn about the economic consequences of a selected method of financing that is relevant for the entrepreneurs operating as companies.

\section{The notion and types of thin capitalisation}

A phenomenon widely known as thin capitalisation is related to the process of selecting a method for financing companies by shareholders or entities - directly or indirectly - affiliated with the shareholders. Neither the term nor its definition have been introduced into the tax law.

The term was first used by tax authorities of OECD member countries for the purpose of naming a practice of multinational groups of companies who, linked by equity, establish subsidiaries with a minimal share capital on the territory of countries known for imposing heavy tax burdens and subsidise these subsidiaries with the debt financing method (Wells, 1993, p. 9). As Froud et al. claim (2000, p. 1261), the fact that large private economic entities are given more and more attention (though not enough considering the role they serve in the contemporary economy) contributes considerably to this process.

There are two basic methods of financing a company:

1. the method of equity financing, and

2. the method of debt financing.

The method of equity financing is based on financing companies with either their own funds or funds provided by the shareholders. Choosing funds for financing is thus dependent on an entity. One of the sources of capital may be the profit allocated for distribution among the entitled entities; this amount is not distributed by way of a resolution adopted at the shareholders' meeting (i.e., the General Meeting of Shareholders) to increase the share capital. In the case of financing by means of the company's own funds, the share capital is increased through retaining the profit. This model is referred to as self-financing and exemplifies internal financing means. In contrast, financing with the funds provided by the shareholders may be considered external financing (Brzeziński \& Hayder, 1997, p. 32-25).
The method of debt financing consists of making the capital available to the company in a form of a loan, credit or bonds, which establishes the relationship of creditor debtor between the financing entity, i.e., the shareholder, and the financed company. Consequently, this situation causes the financing entity to play a double role in relation to the company, one as the creditor and the shareholder.

The phenomenon of thin capitalisation emerges when the activity of a company, or any other legal person, is largely financed by means of loans/credits and at the same time, in view of the statutory provisions, the initial capital of these entities is limited to the minimal level (Paczulski, 2001, p. 165). If such an approach is adopted, thin capitalisation is tantamount to excessive implementation of the debt financing method by the shareholders. This means that the volume of the share capital is too small in comparison to the amount of a company's debt owed to the shareholders.

As far as thin capitalisation is concerned, the need to select a method for financing arises from the necessity to optimise the value of taxation of a company. To a large extent, the method of debt financing is much more attractive for the shareholders who employ it, especially when compared with the method of equity financing. Overesch \& Wamser (2010, p. 569) state that this advantage is perceivable not only on the domestic level, i.e., when the shareholder and the financed company are residents of the same country, but also on the international level, where these entities are residents of two different countries.

The provisions that regulate taxation of the income derived from interest paid to the shareholders, who have chosen the method of debt financing, allow a company to include its expenses incurred in connection to this operation into the category of taxdeductibles. Consequently, the income of the company that is subject to taxation is lowered; such income is considered the positive result of subtraction of taxdeductibles from the revenue.

As Laconick \& O'Sullivan (2000, p. 987) rightly observe, the fact that companies operating in the European and international markets seek financing in external sources in the capital market or by taking out bank loans highlights an important phenomenon influencing the occurrence of thin capitalisation.

Depending on the chosen method of financing, the differences in taxation of income are more visible in 
the case of cross-border settlements where the financing entity is a shareholder residing or having a registered office within the territory of a different country than the one in which the financed company has its registered office. In this case, the rules governing taxation of income may be altered on the basis of stipulations provided in bilateral agreements concerning the avoidance of double taxation (Lipowski, 1999, p. 16). According to Palpaceur (2008, p. 1122), this process is especially noticeable when institutional investors become more significant for the shareholders and when the influence exerted by banks and other entities operating within the financial markets on the strategies of large companies (which are often affiliated) is growing.

In practice, the fact that the method of debt financing is frequently adopted by companies indicates that tax-related aspects constitute the main reasons behind selecting this method. As a result, fiscal authorities and the legislature itself undertake strenuous action with respect to this financing solution. Such strenuous reaction arises because the basic function of tax, as a public levy, is to constitute, first, a source for covering the state's demand for public income, and second, a means of exerting a certain influence on the economic behaviour of taxable persons, which is the so called non-fiscal function of taxes (Gajl, 1992, pp. 124-125; Gomułowicz \& Małecki, 2002, pp. 119-120).

Consequently, it is possible to agree with a claim (Kalinowski 2001; Karwat, 2003; Litwińczuk, 1999) that in this context, thin capitalisation is perceived as an instance of tax avoidance that may be classified as choosing the option involving the least taxation.

\section{Tax-related consequences of the method of debt financing with regard to thin capitalisation}

Legal regulations in OECD member countries are consistent in one way, which is that the interest paid to the shareholders is taxed in a different way than dividends (Hariton, 1994, p. 500). The basic difference is that interest constitutes an expense of a company classified as taxdeductible, unless legal provisions state otherwise. These provisions are especially relevant where regulations limit the phenomenon of thin capitalisation in OECD member countries that have introduced a ban on deducting interest from a company's revenue in the event of excessive debt financing employed by the shareholders.
The following consequences for the tax law arise due to inclusion of interest in the category of expenses constituting tax-deductibles:

1. the expenses incurred by a company from this source are deducted from its revenue, which directly influences the volume of income subject to taxation with corporate income tax; the relevant act of law in Poland: Act of 15 February 1992 on Corporate Income Tax (i.e., Journal of Laws of 2000 No. 54, item 654, as amended);

2. interest is not subject to double taxation in the economic sense, while in the case of dividends such double taxation results from the fact that they are not counted as tax-deductibles;

3. most countries tax interest with tax at source thus the obligation to calculate, collect the tax, and afterwards transfer it to the account of a relevant tax authority is imposed on the debtor - in this case the company distributing the interest - i.e., the taxpayer; the rate of this tax is diverse and may sometimes be reduced in accordance with the stipulations of agreements on avoiding double taxation; it is usually lower than the rate of tax at source for dividends, e.g., in Belgium, Norway, Switzerland or Sweden (Plitz, 1994); and

4. the tax burden of equity tax (or capital tax) does not arise when the method of debt financing is employed even though internal statutory regulations anticipate it (Becker \& Fuest, 2011, p. 595); usually if a company gains capital in the form of a loan or credit, it is subject to tax on civil law transactions; the relevant act of law in Poland: Act of 9 September 2000 on Tax on Civil Law Transactions (Journal of Laws of 2005, No. 41, item 399, as amended).

Considering the abovementioned rules, it must be stated that debt financing is more beneficial than equity financing for the financed company and, above all, for the financing entity. Interest deducted from a company's revenue as a tax-deductible may cause an erosion of income subject to taxation. This phenomenon pushes the governments of many countries to impose tax regulations limiting the option to employ the method of debt financing, especially if the interest is paid to shareholders who are residents of a different country than the one where the company distributing the interest has its registered office (Essers, Michielse, De Bont \& Offermans, 1994). Such an approach seems justified as it results 
directly from the uneven distribution of tax jurisdiction stipulated in the bilateral agreements on avoidance of double taxation (Becker \& Fuest, 2011, p. 600). It is very often the case that the country where the company distributing the interest has its registered office refrains from taxation of the income derived from this source thus exempting the interest from the tax at source - and simultaneously classifies the interest as a tax-deductible leading, which in consequence creates an increased reduction of income subject to taxation (OECD, 1987).

In conclusion, as a consequence of employing the debt financing method, the income of shareholders derived from interest - considered a tax-deductible for the company/debtor - does not bear the economic burden of tax imposed on a company's income before its division and distribution of dividends, as opposed to the dividends payed. As a result, the creditor - the shareholder - is the only entity bearing the burden of income tax imposed on the interest. The choice of the debt financing method also determines the rate of tax on interest stipulated in agreements on avoiding double taxation.

\section{Thin capitalisation against the OECD Model Agreement}

It seems necessary to discuss the issue of interest taxation in view of the OECD Model Agreement. From the legal perspective, the rules governing the way countries that enter an agreement distribute their tax claims with respect to income derived from interest among each other are similar to those serving the avoidance of double taxation of dividends. Demarcation of jurisdiction between the country constituting the source of the interest and the country where the receiver resides is regulated by the OECD Model Agreement.

The OECD Model Agreement acknowledges the right of both of the countries to tax income arising from interest. As with dividends, the country of source has a limited right to tax interest at source; this means that it may tax this income, however, the imposed tax may not exceed - as the matter of principle - 10 per cent of the gross interest. This forces the country of residence of the receiver of the interest to adopt one of the methods that allows it to avoid double taxation on the interest - usually the method of a tax credit. In such a case, the tax on interest collected in the country of source is treated as an advance on the tax on income from interest payable to the country of residence of the shareholder
(Lüthi, 1991; Sieker, 1997). Nevertheless, the fact that tax on interest paid at source is counted towards the tax payable to the country of residence of the receiver of the interest may turn out to be unfavourable to the second country. This is because in accordance with the rules of granting a tax credit, income generated in the country of residence of the receiver is amalgamated with income generated abroad and tax is calculated on the amount determined by way of amalgamation. Then, the tax on interest paid at source is deducted from the calculated tax (Fuest \& Hemmelgarn, 2005, p. 521). Deduction of the tax paid abroad does not encompass the whole amount, but only a part not exceeding the part of the tax before deduction, which is pro rata to the income generated abroad (Białobrzeski, 1998, p. 80; Vogel, 1997, p. 712). Consequently, the shareholders making a decision to adopt the method of debt financing must first and foremost take into account the rate of tax on interest in the country of their residence (Portner, 1996, pp. 267-268; Wiliamson, 1991, pp. 185-186).

The analysis of the abovementioned tax measures leads to the conclusion that the OECD Model Agreement causes the legal situation of a shareholder to be different depending on the method of financing that they adopt. The freedom to alter the provisions of the OECD Model Agreement inclines many countries to exempt interest from tax at source on the basis of bilateral agreements - which is contrary to Article 11 section 2 of the OECD Model Agreement - and de facto means waiving the right to tax this income (Plitz, 1994). This practice is followed in Denmark, Finland, Germany, Norway, the United States, Sweden, and Switzerland. The remaining OECD member countries reserve the right to tax interest at source, however, they impose a lower rate of the tax at source to the principle than the rate of tax at source on dividends (Essers, Michielse, de Bont \& Offermans, 1994; Plitz, 1994).

The OECD Model Agreement stipulates that the interest sourced in one country entering an agreement and paid to a party residing or having a registered office in another country entering an agreement may be taxed by the country of residence of the receiver of this interest. As with dividends, the relevant provision of the OECD Model Agreement does not imply that the country of residence is the only party entitled to tax the income arising from the source (Hughes \& Collier, 1989, pp. 4-5; Jackson, 1990, pp. 319-320). 
The rules governing taxation of the income derived from interest generated in the country of source are also stipulated in the OECD Model Agreement. It proposes that the country of residence of the debtor, or where the debtor has their registered office and the interest has its source, has a limited right to tax interest at source (Gouthiere, 1990, pp. 296-297; de Hosson \& Michielse, 1989, pp. 476-477). However, the right of the country of source to choose a method of collection of this tax is not constricted by the OECD Model Agreement, which also grants perfect freedom as to the form of satisfaction of this tax liability.

The country of source has the right to impose tax on income if one of the following criteria are met:

1. the income from interest is generated on its territory as stipulated by the OECD Model Agreement; a country entering an agreement is considered a source of interest, if the debtor resides or has the registered office or any other permanent establishment, such as a plant or a factory, in it; these two conditions stand in the relationship of a rule and an exception: it is a rule to take into account the place of residence or the place of the registered office of the debtor but it is an exception to take into account the place where a permanent establishment, such as a plant or a factory is situated;

2. the interest is paid in favour of a person residing or having a registered office in a territory of the other country entering an agreement; and

3. the receiver of interest is simultaneously the beneficial owner of the income derived from this source and not a formal one - i.e., not an agent, plenipotentiary or proxy of the actual receiver of the interest; the concept of a beneficial owner is relevant for both categories of income that shareholders are entitled to according to the method for financing they choose (Sasseville, 1995, p. 33).

In the three cases above (items 1-3), the tax collected by the country of source may not exceed 10 per cent of gross interest. This rate is considered a reasonably minimal tax burden on interest because the country of source is entitled to tax income generated on its territory, which arises from investments financed with capital raised from the receivables on which the interest is actually paid. However, countries entering an agreement may decide upon a different rate than 10 per cent of the tax at source. The country of source may exempt interest from tax at source, which in fact means waiving the right to tax this income. Such a practice is adopted by OECD member countries whose internal legal regulations do not stipulate the taxation of interest, e.g., the Netherlands (Doernberg, 1995, p. 12). According to Devereux, Lockwood \& Redoano (2008, p. 1221), these conclusions are of special significance in the period of harmonisation of the tax policy on corporate income tax, especially in the context of the global economic crisis.

Provisions concerning the taxation of interest stipulated in bilateral agreements may lead to excessive adoption of the method of debt financing. The financed company and the shareholder may formulate an agreement postulating an excessive interest rate, i.e., interest calculated at a significantly higher rate than the one usually established when transactions take place between unaffiliated entities. Thus, it is rightly assumed that in such a case the value of interest is not in line with the arm's length principle. Therefore, tax authorities gain the right to question the interest rate and make corrections of the profit derived from it in accordance with the provisions regulating the phenomenon of shifting income between affiliated entities (Valchy, 2008, p. 661). In consequence, part of the interest exceeding the interest rate adopted in trading between unaffiliated entities may be deemed the so-called constructive dividend. The excessive interest may eventually be taxed as income derived from participation in shares (Gäverth, 1999). The issue of interest in breach of the arm's length principle is also regulated by Article 11 section 6 of the OECD Model Agreement. The provisions of this agreement indicate that the part of interest regarded as excessive may be exempted and correction of the profit transferred in this form is allowed. It also stipulates that the correction made may not exceed the amount of interest that parties would have agreed upon if they had acted irrespectively of the particular relationship between them, which led to the inflated interest rate in the first place. Such a correction may consist of changing the classification of the income arising from the excessive interest to the so-called constructive dividend, and should take into consideration the legal nature of such income - i.e., the type of receivables on which interest is paid, its economic purpose and the substance of liability - like the mutual rights and obligations of the parties. If excessive interest is paid on the receivables of a company towards the shareholders, then nothing 
prevents taxing such excess in line with the rules on taxation of income from dividends (Helminen, 1999).

\section{Conclusion}

The analysis of the tax-related consequences of providing funds for companies using the method of debt financing chosen by shareholders leads to the conclusion that debt financing is more beneficial than equity financing. From the point of view of taxation, the fundamental differences between debt and equity financing are as follows:

- interest, in contrast to dividends, is considered a tax-deductible for the financed company;

- interest is deducted from the revenue, which does not lead to double economic taxation as in the case of dividends;

- from an international perspective on the matter, the rate of tax at source on interest collected in the country of residence of a company is lower than the rate of tax at source imposed on dividends in this country;

- many bilateral agreements drafted on the basis of the OECD Model Agreement postulate that the country of source relinquishes its right to tax income derived from interest, which rarely happens in the case of dividends because the renouncement of the right to tax income from dividends with tax at source by the country of residence of a company distributing the dividends is exceptional; this results from the necessity to employ the method of a tax credit in the country of residence to avoid double taxation of income arising from dividends (Avery Jones, et al., 1996, p. 128).

- in the OECD member countries whose legislation suggests taxation of capital, tax obligations arise as a consequence of adopting the method of debt financing as opposed to equity financing.

It is indisputable that a company should reasonably assess the tax-related consequences connected to the process of financing before choosing between the method of debt or equity financing. This tax-related effect constitutes one of the basic factors influencing a company's economic position. Because the tax-related consequences when using the method of debt financing are much more beneficial for companies than those of equity financing, they clearly exert influence on the economic effect. Because every economic en- tity takes an economic point of view aiming to choose the least burdensome tax policy for itself, allowing it to achieve its financial goals.

\section{References}

Avery Jones, J., De Broe, L., Van de Wiele, M., Ellis, M. J., Van Raad, K., \& Fonteneau, P. (1996). Credit and Exemption under Tax Treaties in Cases of Differing Income Characterization. European Taxation, 36(4), 118-134.

Becker, J., \& Fuest, C. (2011). Optimal tax policy when firms are internationally mobile. International Tax and Public Finance, 18(5), 580-604.

Białobrzeski, J. (1998). Międzynarodowe Prawo Podatkowe. Komentarz [International Tax Law. Commentary], Warszawa: Difin.

Brzeziński, B., \& Hayder, R. (1997). Niedostateczna kapitalizacja spółek kapitałowych [Thin Capitalisation of Companies]. Monitor Podatkowy, 2, 32-35.

Clausing, K. (2007). Corporate Tax Revenues in OECD Countries. International Tax and Public Finance, 14, 115-133.

Devereux, M. P., Lockwood, B., \& Redoano, M. (2008). Do Countries Compete Over Corporate Tax Rates. Journal of Public Economics, 92(5-6), 1210-1235.

Doernberg, R. L. (1995). Amending the OECD Model Treaty and Commentary Response to Corporate Tax Integration. In: International taxation of dividends reconsidered in light of corporate tax integration: proceedings of a seminar organised jointly with OECD in Toronto in 1994 during the 48th Congress of the International Fiscal Association. (pp. 12-14). London, UK: Kluwer Law International.

Essers, P., Michielse, G., De Bont, G., \& Offermans, R. (1994). Some Fiscal Aspects of Financing Structures within a Group of Companies and Thin Capitalization Approaches in Europe. Report of the Wintercourse, EC Tax Review, 4, 165-174.

Froud, J., Haslam, C., Johal, S., \& Williams. K. (2000). Shareholder Value and Financialization: Consultancy Promises, Management Moves. Economy and Society, 29(1), 80-110.

Fuest, C., \& Hemmelgarn, T. (2005). Corporate Tax policy, foreign firm ownership and thin capitalization. Regional Science and Urban Economics, 35(5), 508-526.

Gajl, N. (1992). Teorie podatkowe $w$ świecie [World's Tax Theories], Warszawa: Wydawnictwo PWN. 
Gäverth, L. (1999). Skattplanering och Kapitalisierungsfrågor [Tax Planning and Capitalization Questions] (doctoral dissertation), Uppsala University, Sweden.

Gomułowicz, A., \& Małecki, J. (2002). Podatki i prawo podatkowe [Taxes and Tax Law], Wydawnictwo LexisNexis, Warszawa.

Gouthiere, B. (1990). Thin Capitalization and the OECD Model Convention, Intertax, 6-7, 296-297.

Hariton, D. P. (1994). Essay: Distinguishing Between Equity and Debt in the New Financial Environment, Tax Law Review, 49(3), 497-501.

Helminen, M. (1999). The Dividend Concept in International Tax Law. London, UK: Kluwer Law International.

De Hosson, \& F. C., Michielse, G. M. (1989). Treaty Aspects of Thin Capitalization Issue - A Review of the OECD Report, Intertax, 11, 476-477.

Hughes, T., \& Collier, R. (1989). Thin Capitalization Following the OECD Report: A Country Survey, Tax Planning International Review, 16(8), 4-5.

Jackson, B. (1990). International: Thin Capitalization, European Taxation, 11, 319-320.

Kalinowski, M. (2001). Granice legalności unikania opodatkowania $w$ polskim systemie podatkowym [Legal Boundaries of Tax Avoidance in the Polish Tax System], Toruń: Wydawnictwo TNOiK.

Karwat, P. (2003). Obejście prawa podatkowego [Circumnavigation of Tax Law], Przegląd Podatkowy, 2, 46-51.

Lazonick, W., \& O’Sullivan, M. (2000). Maximising Shareholder Value, A New Ideology for Corporate Governance, Economy and Society, 29(1), 13-35.

Lipowski, T. (1999). Umowy o unikaniu podwójnego opodatkowania [Agreements on Avoiding Double Taxation]. Sopot: Wydawnictwo Prawnicze LEX.

Litwińczuk, H. (1999). Obejście prawa podatkowego $w$ świetle doświadczeń międzynarodowych [Circumnavigation of Tax Law in the Light of International Experience], Przegląd Podatkowy, 9, 3-5.

Lüthi, D. (1991). Thin Capitalization of Companies in International Tax Law, Intertax, 19(10), 446-453.

OECD (1987). Report on „Thin Capitalization”. Issues in International Taxation, 2, 34.

Overesch, M., \& Wamser, G. (2010). Corporate tax planning and thin-capitalization rules: evidence from a quasi-experiment, Applied Economics, 42(5), 563-573.
Paczulski, A. (2001). Opodatkowanie dochodów kapitałowych osób prawnych [Taxation of Capital Income of Legal Persons], Warszawa: Wydawnictwo C.H. Beck.

Palpaceur, F. (2008). Bringing the Social Context Back In: Governance and Wealth Distribution in Global Commodity Chains, Economy and Society, 37(3), 393-419.

Plitz, D. (1994). General Report, Studies on International Fiscal Law, LVVVIb, 94.

Portner, R. (1996). Thin Capitalization and Tax Treaties, Unlimited Right to Tax Dividends and Interest at Source, European Taxation, 8, 266-268.

Sasseville, J. (1995). Article 10 of the OECD Model Tax Convention and Different Approaches to Integration. In: International taxation of dividends reconsidered in light of corporate tax integration: proceedings of a seminar organised jointly with OECD in Toronto in 1994 during the 48th Congress of the International Fiscal Association. London (UK): Kluwer Law International.

Sieker, K. (1997). Germany: Thin Capitalization and Transfer Pricing, International Transfer Pricing Journal, 4(4), 222.

Valchy, J. (2008). Investigating a Thin-Capitalization Rule: an option-based analysis, Politicka Ekonomie, 56(5), 656-668.

Vogel, K. (1997). Klaus Vogel on Double Taxation Conventions. A Commentary on the OECD, UN, US Model Conventions for the Avoidance of Double Taxation of Income and Capital with Particular Reference to German Treaty Practice ( $\left.3^{\text {rd }} \mathrm{ed}\right)$. London, UK: Kluwer Law International.

Wells, A. (1993). Current Developments with Thin Capitalization, The Tax Journal, 3, 9.

Wiliamson, S. (1991). Thin Capitalization: A Critical Review. Australian Tax Forum, (8)2, 185-186. 